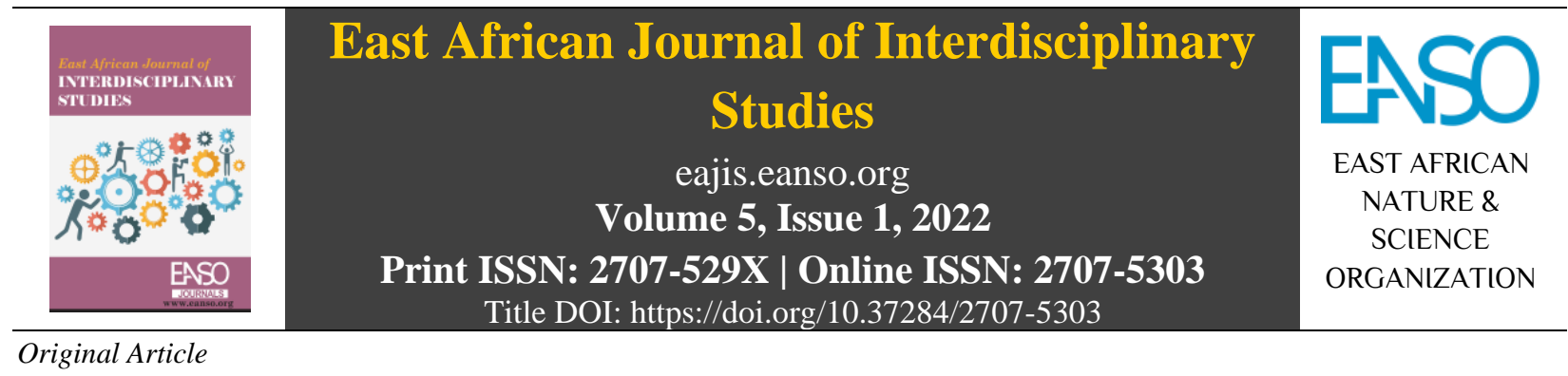

\title{
Relationship between Availability of Institutional Resources and Academic Performance of Catholic-sponsored Secondary Schools in Kericho Diocese, Kenya.
}

\author{
Stephen Nyamwaya Obwoge, ${ }^{1 *}$ Dr. Hellen W. Sang, PhD ${ }^{1} \&$ Dr. Lydia Langat, PhD ${ }^{1}$ \\ ${ }^{1}$ University of Kabianga, P. O. Box 2030-20200, Kericho, Kenya. \\ *Author for Correspondence Email: steveosa8@gmail.com
}

Article DOI: https://doi.org/10.37284/eajis.5.1.559

\section{Date Published: ABSTRACT}

21 February 2022 The academic performance of the most private and public secondary schools in Kenya has indicated rapid decline, which has hindered the learning Keywords: institutions from achieving their set goals. The deteriorated performance may be attributed to several factors, such as insufficient resources. One vital

Institution Resources, Strategic Plan Implementation,

Performance of Catholic-Sponsored Secondary School. mechanism to be employed by the schools in achieving good performance is the effective utilization of institutional resources. However, there is limited literature on to what extent institutional resources availability can improve the performance of secondary schools. On this note, the paper sought to examine the relationship between institutional resources availability and academic performance of Catholic-sponsored secondary schools in Kericho Diocese, Kenya. The study was anchored on resource-based theory. A correlational research design was employed, and the target population was comprised of 789 graduate teachers. Stratified random sampling was also used to determine a sample size of 266 respondents. Primary data was obtained by use of a structured questionnaire. Quantitative data were analysed using correlation and regression analysis and presented using frequency tables. The findings from the study revealed a statistically significant relationship between institutional resources availability and academic performance of Catholic-sponsored secondary schools $(\mathrm{R}=0.659$; $\beta=0.223 ; p<0.05)$. The study results indicated that institutional resources availability influenced Catholic-sponsored secondary schools' performance by $67.2 \%(\mathrm{R} 2=0.672)$. Therefore, the study recommends that secondary schools effectively utilize institution resources to implement the strategic plan, which will improve their performance.

\section{APA CITATION}

Obwoge, S. N., Sang, H. W., \& Langat, L. (2022). Relationship between Availability of Institutional Resources and Academic Performance of Catholic-sponsored Secondary Schools in Kericho Diocese, Kenya East African Journal of Interdisciplinary Studies, 5(1), 22-29. https://doi.org/10.37284/eajis.5.1.559.

$22 \mid$ This work is licensed under a Creative Commons Attribution 4.0 International License. 


\section{CHICAGO CITATION}

Obwoge, Stephen Nyamwaya, Hellen W. Sang and Lydia Langat. 2022. "Relationship between Availability of Institutional Resources and Academic Performance of Catholic-sponsored Secondary Schools in Kericho Diocese, Kenya". East African Journal of Interdisciplinary Studies 5 (1), 22-29. https://doi.org/10.37284/eajis.5.1.559.

\section{HARVARD CITATION}

Obwoge, S. N., Sang, H. W., \& Langat, L. (2022) "Relationship between Availability of Institutional Resources and Academic Performance of Catholic-sponsored Secondary Schools in Kericho Diocese, Kenya", East African Journal of Interdisciplinary Studies, 5(1), pp. 22-29. doi: 10.37284/eajis.5.1.559.

\section{IEEE CITATION}

S. N. Obwoge, H. W. Sang, \& L. Langat, "Relationship between Availability of Institutional Resources and Academic Performance of Catholic-sponsored Secondary Schools in Kericho Diocese, Kenya", EAJIS, vol. 5, no. 1, pp. 22-29, Feb. 2022.

\section{MLA CITATION}

Obwoge, Stephen Nyamwaya, Hellen W. Sang and Lydia Langat. "Relationship between Availability of Institutional Resources and Academic Performance of Catholic-sponsored Secondary Schools in Kericho Diocese, Kenya". East African Journal of Interdisciplinary Studies, Vol. 5, no. 1, Feb. 2022, pp. 22-29, doi:10.37284/eajis.5.1.559.

\section{INTRODUCTION}

The political, social, and economic development of a country is based on the investment of education, and this brings positive change in children's lives. Since independence, there have been several reforms in education systems in Kenya that aim to enhance access, quality, and equity of education to all (Inviolata, 2018). Due to various reforms in the education sector such as free primary education, subsidized free day secondary education, and a hundred percent transition from primary to secondary school, various institutions, and other stakeholders have played a key role in providing resources to both primary and secondary schools which have facilitated their performance. For instance, catholic churches have sponsored various learning institutions (Merry \& Boterman, 2020).

The main goal of the teaching and learning process is to bring desirable change in the learner, and this shapes their behavior which is through critical thinking. The process takes place in an environment that is structured to create a conducive learning environment. Institutional resources play an essential role in acquiring school facilities, which constitutes a significant learning environment component (Eric \& Ezeugo, 2019).

In Indonesia, Bakar (2018) asserts that the quality of education can be determined by assessing the quality of the students produced. One of the indicators that measure that quality is the academic performance of the student, and this performance is influenced by the tutor's skills and competency. A study by Prasetio et al. (2017) that sought to determine the effect of tutor skills and competency and academic performance in higher education indicated a significant positive effect on the students' academic performance.

The adoption of electronic learning resources offers a conducive learning environment that transforms the teaching process in a learning institution. Electronic learning has become a popular learning resource in educational institutions in Nigeria because of the vast growing internet technology. Electronic learning increases accessibility to save time, reduces cost, and offers quality education, thus improving students' performance. However, the study findings indicated that there was no significant relationship between electronic learning resources and the performance of physics (Akanbi, 2020)

According to Mendy et al. (2021), the Catholic Church is one of the churches involved in introducing western education in Kenya. The churches continue to establish learning institutions that play a pivotal role in offering quality education. They asserted that the performance of secondary schools within Nairobi archdioceses was influenced by sufficient allocation of resources by Catholic Churches.

\section{Problem Statement}

Learning institutions play an essential role in society. Not only do they equip students with knowledge and skills, but they create employment 
opportunities, improve living standards, and foster developments. Learning institutions range from primary schools to higher learning institutions such as universities. In Kenya, catholic sponsored schools are appreciated due to their service quality, which is duplicated in their excellent academic performance. However, this is not the same case with Kenya Certificate of Secondary Education performance in most secondary schools within the Catholic Diocese of Kericho. There is a disconnect because the schools are not performing well like other catholic sponsored secondary schools in other parts of the country. There are scanty studies conducted to assess the effect of poor academic performance. Therefore, the current study sought to determine the relationship between institutional resources availability and academic performance of catholic-sponsored Secondary schools in Kericho Diocese, Kenya.

\section{LITERATURE REVIEW}

\section{Theoretical Review}

The study was underpinned on the resource-based theory, which was propounded by Wernerfelt (1984). The theory postulates that resources are critical to superior firm performance. According to Barney (1991), if a resource has valuable, rare, imperfectly imitable, and not substitutable attributes, the resource can enable the firm to gain and sustain a competitive advantage. "Firm resources and sustained competitive advantage" are extensively quoted as a significant work in the emergencies of the Resource-based theory. The question that is always asked is, what makes your business or organization unique? Resource-Based View (RBV) is very important in strategic planning and implementation (Barney, 1991). According to Kraaijenbrink, Spender, and Groen (2010), for a firm to attain a state of competitive advantage, it must acquire and control Valuable, Rare, Inimitable, and non-subsumable (VRIN) resources and capabilities. The resource-based theory contends that possessing strategic resources provides an organization with a golden opportunity to develop competitive advantages over its rivals. The resource-based theory urges that firms keep resources, a subset of which enable them to achieve a competitive advantage and a subset of those that lead to superior long-term performance.
According to Pearce-Higgins et al. (2007), each organization grows its competence from various resources, and when these resources are developed, it leads to a firm's competitive advantage. The resource-based approach shows that superior structure and systems in firms make them profitable. This theory is related to the study because it gives managers the green light to know whether to go for mergers and acquisitions. They can also understand how to allocate resources to various departments according to the strategy. Further, the theory gives careful analysis and identification of an organization's advantage on the strategy based on its unique mix of tangible skills, capabilities, and assets. Having a comparative advantage will mean that those firms have rare resources among the competitors. Therefore, the resource-based view was linked with the third variable, organizational resources, and the research hypothesis of the study.

\section{Empirical Review}

A study conducted in Indonesia by Prasetio et al. (2017) sought to explore the tutors' skills and competency on academic performance in higher education. The study adopted a mixed research design. The target population was composed of 780 students and 150 tutors. Stratified simple random sampling and simple random sampling techniques were used to obtain 250 students and 100 tutors who formed 350 respondents. Self-administered structured questionnaires and academic records from the institutions were used to obtain primary data and secondary data, respectively. Data were analyzed descriptively and inferentially. Linear regression was applied to determine the relationship between the variables. It was revealed that tutors' skills and competence had a significant relationship with students' academic performance. The study concluded that it is important for learning institutions to have skilled and competent personnel resources to foster better performance.

Akanbi (2020) examined the influence of electronic learning resources and the performance of the senior school in Illorin, Nigeria. The study adopted a survey research design where a sample size of 60 respondents was selected by employing a multiplestage sampling technique. Primary data was obtained through the use of two structured checklists. ANOVA was adopted to test the research 
hypotheses. The findings illustrated that electronic learning resources had an insignificant relationship with the performance of physics. The study recommended that tutors need to be trained on how to use electronic learning resources, which will help the tutors with knowledge and skills.

A study conducted by Mendy et al. (2021) sought to assess the influence of resource allocation on the academic performance of Catholic-sponsored secondary schools in the Archdiocese of Nairobi, Kenya. A cross-sectional research design was adopted where a stratified random sampling technique was adopted to obtain an accessible population of 24 schools which were grouped into strata. A simple random sampling technique was also applied to come up with a sample size of 8

\section{Figure 1: Conceptual framework}

\section{Independent Variable}

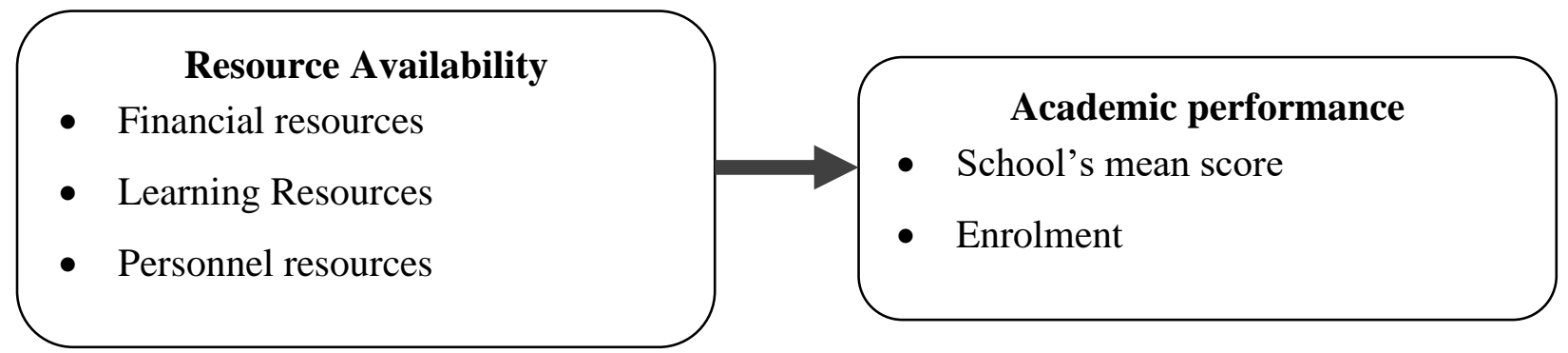

This study adopted a Correlational research design whereby the data collected and recorded was used to unveil the relationship between the variables. The target population was 789 , comprising of teachers drawn from all the 75 catholic sponsored secondary schools in the dioceses of Kericho. A stratified and simple random sampling technique was employed to obtain respondents for the study, where Yamane's formula was used to obtain a sample size of 266. Primary data was collected through the administering closed-ended questionnaire. The questionnaire was checked for content validity. To ensure the validity of the questionnaire, colleagues, supervisors, and other research experts in the study area were used to make necessary corrections.

On the other hand, reliability was determined by conducting a pre-test of the instrument. Inferential

\section{RESEARCH METHODOLOGY}

schools. Primary data was collected through a selfadministered questionnaire and interviews. Descriptive and inferential statistics were adopted to analyze data. The findings showed that sufficient learning and instructional materials had a significant relationship with academic performance.

According to Creswell 2015), a conceptual framework is a diagram that connects and explains the relationship of the variables under study. This study used institutional resource availability as the independent variable and academic performance of Catholic-sponsored schools as the dependent variable.

\section{Conceptual Framework}

\section{Dependent Variable}

statistics and descriptive statistics, percentages, and frequency were employed to present quantitative data in frequency tables. Regression analysis models were applied to establish the relationship between the variable and the nature of that relationship.

\section{RESULTS AND DISCUSSION}

Data were analysed using both descriptive and inferential statistics. Regression and correlations analysis was carried out to ascertain the nature and direction of the relationship between institutional resource availability and academic performance of the catholic sponsored schools in Kericho Diocese, Kenya.

\section{Descriptive Statistics}

The study used a five-point Likert scale to measure the respondents' opinion on the relationship

25 | This work is licensed under a Creative Commons Attribution 4.0 International License. 
between institutional resource availability and the academic performance of the catholic sponsored schools. On the Likert scale, 5 represents strongly agree, 4 represents agree, 3 represents neutral while
2 is disagree, and 1 represents strongly disagree. Obtained respondent opinions are presented in Table 1.

Table 1: Institutional Resources

\begin{tabular}{|c|c|c|c|c|c|c|c|}
\hline Statement & SA & $\mathbf{A}$ & $\mathbf{N}$ & D & SD & Mean & Std. Dev \\
\hline $\begin{array}{l}\text { The school management allocates } \\
\text { enough financial resources to } \\
\text { enhance academic performances }\end{array}$ & $\begin{array}{l}106 \\
(44 \%)\end{array}$ & $\begin{array}{l}102 \\
(42 \%)\end{array}$ & $\begin{array}{l}14 \\
(6 \%)\end{array}$ & $\begin{array}{l}13 \\
(5 \%)\end{array}$ & $\begin{array}{l}6 \\
(3 \%)\end{array}$ & 4.20 & 0.949 \\
\hline $\begin{array}{l}\text { The school has well-trained human } \\
\text { resources experts who have helped in } \\
\text { enhancing academic performances }\end{array}$ & $\begin{array}{l}85 \\
(35 \%)\end{array}$ & $\begin{array}{l}110 \\
(47 \%)\end{array}$ & $\begin{array}{l}13 \\
(5 \%)\end{array}$ & $\begin{array}{l}27 \\
(11 \%)\end{array}$ & $\begin{array}{l}6 \\
(3 \%)\end{array}$ & 4.00 & 0.740 \\
\hline $\begin{array}{l}\text { The school has in place technological } \\
\text { resources to improve on academic } \\
\text { performance }\end{array}$ & $\begin{array}{l}84 \\
(35 \%)\end{array}$ & $\begin{array}{l}110 \\
(47 \%)\end{array}$ & $\begin{array}{l}27 \\
(11 \%)\end{array}$ & $\begin{array}{l}14 \\
(7 \%)\end{array}$ & $\begin{array}{l}6 \\
(3 \%)\end{array}$ & 4.05 & 0.958 \\
\hline $\begin{array}{l}\text { There are enough institutional } \\
\text { resources available that support } \\
\text { academic performance }\end{array}$ & $\begin{array}{l}113 \\
(46 \%)\end{array}$ & $\begin{array}{l}88 \\
(36 \%)\end{array}$ & $\begin{array}{l}20 \\
(8 \%)\end{array}$ & $\begin{array}{l}14 \\
(6 \%)\end{array}$ & $\begin{array}{l}5 \\
(2 \%)\end{array}$ & 4.19 & 0.987 \\
\hline
\end{tabular}

Table 1 indicates that $106(44 \%)$ respondents strongly agreed that school management allocates enough financial resources to enhance academic performance. On the same statement, 102(42\%) agreed, 14(6\%) were neutral, 13(5\%) disagreed and $6(3 \%)$ strongly disagreed $(M=4.20 ; S D=0.949)$. On whether the school has a well-trained human resources expert who has helped in enhancing academic performances; $85(35 \%)$ of the respondents strongly agreed, $110(47 \%)$ agreed, $3(5 \%)$ were neutral, $27(11 \%)$ disagreed and 6(3\%) strongly disagreed $(M=4.00 ; S D=0.740)$.

Further, when asked if the school has in place technological resources to improve on academic performance; $84(35 \%)$ strongly disagreed, $110(47 \%)$ agreed, $27(11 \%)$ were neutral, 14(7\%) disagreed, and 6(3\%) strongly disagreed $(M=4.05$; $S D=0.958$ ) and lastly, on whether there are enough institutional resources available that supports academic performance; 113(46\%) respondents strongly agreed, $88(36 \%)$ agreed, 20(8\%) were neutral, 14(6\%) disagreed and 5(2\%) strongly disagreed $(M=4.19 ; S D=0.987)$. The findings indicated that institutional resources were the major contributor to the academic performance of catholic sponsored secondary schools in the Kericho diocese. A study by Prasetio et al. (2017) and Mendy et al. (2021) concurred with these findings indicating that personnel and financial resources, respectively, influenced academic performance. However, study findings by Akanbi (2020) disagreed with these findings indicating that learning resources did not influence academic performance.

\section{Inferential Statistics}

The study used correlation and regression analysis to assess the nature and direction of the relationship between institutional resources and academic performance of Catholic Sponsored Secondary Schools.

\section{Correlation Analysis}

Correlation analysis was carried out to assess the direction of the relationship between the independent variables and dependent variables. 
East African Journal of Interdisciplinary Studies, Volume 5, Issue 1, 2022

Article DOI: https://doi.org/10.37284/eajis.5.1.559

Table 2: Correlation Analysis

\begin{tabular}{lll}
\hline & & Performance \\
\hline Institutional resources & Pearson Correlation & $0.659^{* *}$ \\
& Sig. (2-tailed) & .000 \\
$\mathrm{~N}$ & 241 \\
\hline
\end{tabular}

Results from correlation analysis established a strong positive relationship between Institutional resources and academic performance of Catholic Sponsored Secondary Schools $(\mathrm{R}=0.659, \mathrm{p}<0.05)$. These findings are in line with those of Prasetio et al. (2017), and Mendy et al. (2021) concurred with these findings indicating that personnel and financial resources respectively had a significant relationship with academic performance. However, study findings by Akanbi (2020) contradicted these findings. It was found that learning resources indicated an insignificant effect on academic performance.

Table 3: ANOVA

\begin{tabular}{lllllll}
\hline Model & & Sum of Squares & Df & Mean Square & F & Sig. \\
\hline 1 & Regression & 86.018 & 4 & 21.504 & 121.238 & $0.000^{\mathrm{b}}$ \\
& Residual & 41.860 & 236 & 0.177 & & \\
& Total & 127.878 & 240 & & & \\
\hline
\end{tabular}

a. Dependent Variable: Academic Performance of Catholic Sponsored Secondary Schools

b. Predictors: (Constant), Institutional Resources

The findings from Table 3 indicate a significance level of 0.000 which is less than 0.05 ( $\mathrm{p}=$ $0.000<0.05)$. This implies that the model was statistically significant in explaining the influence of the independent variables on the dependent variable. The findings also revealed that the calculated value of $\mathrm{F}$ was greater than the tabulated $F$ at a 0.05 level of significance, implying the model was significant.

\section{Regression Analysis}

The researcher carried out a regression analysis to assess the relationship between the dependent and independent variables of the study. The results are tabulated in Table 3.

Table 4: Regression model summary

\begin{tabular}{lllllc}
\hline Model & R & R Square & $\begin{array}{l}\text { Adjusted R } \\
\text { Square }\end{array}$ & $\begin{array}{l}\text { Std. Error of } \\
\text { Estimate }\end{array}$ & the Durbin-Watson \\
\hline 1 & 0.820 & 0.672 & 0.667 & 0.42116 & 2.359 \\
\hline a. Predictors: (Constant), Institutional Resources \\
b. Dependent Variable: Academic performance of Catholic Sponsored Secondary Schools
\end{tabular}

The model summary indicates that the independent variable under study (Institutional Resources) explains $0.672(67.2 \%)$ of the academic performance of catholic sponsored secondary schools in Kericho diocese, Kenya, as indicated by the coefficient of determination $\left(\mathrm{R}^{2}\right)$. Therefore, this implies that other factors that were not considered under this study contributed $32.8 \%$ of the performance of catholic sponsored secondary schools.

\section{Testing of Hypothesis}

The study tested the following hypothesis.

$\boldsymbol{H}_{01}$ : There is no significant relationship between institutional resources and academic 
performance in Catholic-sponsored secondary schools in Kericho Diocese.

The study revealed a significant statistical relationship between institutional resources and academic performance of catholic sponsored secondary schools in Kericho Diocese $(\mathrm{R}=0.659 ; \beta$ $=0.223 ; \mathrm{p}<0.05)$. Therefore, the null hypothesis was rejected, and the alternative hypothesis was accepted. These findings were in line with Prasetio et al. (2017), who established a significant relationship between personnel resources and academic performance in higher education in Indonesia. Also, Mendy et al. (2021) established a significant relationship between financial resources and the academic performance of Catholicsponsored secondary schools in the Archdiocese of Nairobi, Kenya.

\section{CONCLUSION AND RECOMMENDATION}

The findings revealed that the availability of institutional resources influenced the schools' academic performance. The majority of the respondents agreed that school management allocates enough financial resources to enhance academic performance, school management allocates enough financial resources to enhance academic performance, and the school has welltrained human resources experts who have helped enhance academic performance. In general, the respondents revealed that there are enough institutional resources available that support academic performance. In conclusion, the findings indicated that there was a significant statistical relationship between institutional resources and academic performance in catholic sponsored secondary schools in Kericho. The study recommends that schools mobilize, allocate, and utilize the available resources to improve their academic performance.

\section{REFERENCES}

Akanbi, A. O. (2020). Availability and Utilisation of E-Learning Facilities in the Teaching of Senior School Physics in Ilorin, Nigeria. Journal of Education and Learning (EduLearn), 14(3), 331-337.

Bakar, R. (2018). The influence of professional teachers on Padang vocational school students' achievement. Kasetsart Journal of Social Sciences, 39(1), 67-72.

Barney, J. B. (1991). Is the resource-based "view" a useful perspective for strategic management research? Yes. Academy of management review, 26(1), 41-56.

Eric, A., \& Ezeugo, C. R. (2019). Physical resources availability and the academic performance of students in the universal basic education scheme, Rivers State. International Journal of Innovative Development and Policy Studies, 7 (1), 13-23.

Inviolata, M. (2018). Influence of Religious Sponsorship on Academic Performance by Protestant and Catholic Secondary Schools in Kenya: A Comparative Study in Trans-Nzoia County, Kenya (Doctoral dissertation). Moi University.

Kraaijenbrink, J., Spender, J. C., \& Groen, A. J. (2010). The resource-based view: A review and assessment of its critiques. Journal of management, 36(1), 349-372.

Mendy, J. M., Titus, M., \& Muli, C. (2021). Resource allocation in strategic planning and school performance in Catholic Church owned secondary schools in Nairobi Archdiocese, Kenya. International Journal of Social and Development Concerns, 14(3), 29-45.

Merry, M. S., \& Boterman, W. (2020). Educational inequality and state-sponsored elite education: the case of the Dutch gymnasium. Comparative Education, 56(4), 522-546.

Pearce-Higgins, J. W., Grant, M. C., Robinson, M. C., \& Haysom, S. L. (2007). The role of forest maturation in causing the decline of Black Grouse Tetrao tetrix. Ibis, 149(1), 143-155.

Prasetio, A. P., Azis, E., Fadhilah, D. D., \& Fauziah, A. F. (2017). Lecturers' professional competency and students' academic performance in indonesia higher education. International Journal of Human Resource Studies, 7(1), 86-93.

Wernerfelt, B. (1984). A resource-based view of the firm. Strategic management journal, 5(2), 171180.

28| This work is licensed under a Creative Commons Attribution 4.0 International License. 